\title{
HUBUNGAN POLA ASUH ORANG TUA TERHADAP KEMANDIRIAN ANAK DI TK WIDYA BAKTI DESA NONGAN, KECAMATAN RENDANG, KABUPATEN KARANGASEM
}

\author{
The Relationship of Parenting Patterns to Children's Independence at Widya \\ Bakti TK Widya Bakti, Nongan Village, Rendang District, Karangasem Regency
}

\author{
AA. Kompiang Ngurah Darmawan ${ }^{1}$, Ni Putu Amelia Puspita ${ }^{2}$ \\ ${ }^{1}$ Prodi S1 Keperawatan, Stikes Bina Usada, Indonesia \\ ${ }^{2}$ Prodi S1 Keperawatan, Stikes Bina Usada, Indonesia \\ Korespondensi: AA. Kompiang Ngurah Darmawan dan ngurahdarmawan32@gmail.com
}

\begin{abstract}
ABSTRAK
Latar Belakang: Pola asuh orang tua adalah cara atau metode yang ditempuh orang tua dalam mengasuh dan menerapkan kemandirian kepada anaknya dalam membentuk watak, kepribadian, dan memberikan nilai-nilai bagi anak agar dapat menyesuaikan diri dengan lingkungan. Kemandirian anak dibentuk dari lingkungan yang utama yaitu keluarga dan pola asuh orang tua yang akan mempengaruhinya. Apabila kemandirian anak tidak dilatih sejak dini oleh orang tua maka akan mengganggu kehidupan sosial anak dan anak tidak dapat bersosialisasi dengan baik di lingkungannya. Tujuan Penelitian: tujuan dari penelitian ini untuk mengetahui hubungan pola asuh orang tua terhadap kemandirian anak di TK Widya Bakti Desa Nongan, Kecamatan Rendang, Kabupaten Karangasem. Metedologi: Penelitian ini menggunakan metode kuantitatif deskriptif dengan pendekatan Cross Sectional, dengan jumlah sampel sebanyak 38 orang. Teknik sampling dengan cara non probability sampling yaitu total sampling. Instrument pengumpulan data dengan menggunakan kuesioner pola asuh orang tua dan kuesioner kemandirian anak. Data dianalisis dengan menggunakan uji Spearman's rho. Hasil: Hasil menunjukkan bahwa sebagian besar pola asuh orang tua berada pada kategori cukup baik, yaitu sebanyak 20 responden atau $52,6 \%$. Hasil analisis kemandirian anak menunjukkan sebagian besar anak memiliki tingkat kemandirian yang telah berkembang sesuai harapan, yaitu sebanyak 23 responden (60,5\%). Hasil analisis menggunakan uji Spearman's rho didapatkan hasil nilai $\mathrm{p}$-value $=0,000$ yang berarti nilai $\mathrm{p} \leq 0,05$ dengan nilai Correlation Coefficient ( $\mathrm{r}$ ) sebesar 0,851 . Hasil ini mengindikasikan bahwa Ho dalam penelitian ditolak yang artinya ada hubungan yang kuat antara pola asuh orang tua terhadap kemandirian anak di TK Widya Bakti Desa Nongan, Kecamatan Rendang, Kabupaten Karangasem. Kesimpulan: Berdasarkan penelitian tersebut diharapkan para orang tua khususnya yang memiliki anak usia prasekolah agar memperhatikan pola pengasuhan yang diberikan agar tidak mengganggu perkembangan mental anak.
\end{abstract}

Kata kunci: Pola asuh orang tua; kemandirian anak.

\section{ABSTRACT}

Background: The foster parents method are the way how to care and apply independence to their children in forming character, personality, and gave moral 
AA. Kompiang Ngurah Darmawan \& Ni Putu Amelia Puspita: Hubungan Pola Asuh Orang Tua terhadap Kemandirian Anak di TK Widya Bakti Desa Nongan, Kecamatan Rendang, Kabupaten

Karangasem

value for the children. The independence of the main environmental formed from the family and the influence it will fostered parent. When the children were not prepared independence early, the children whould have more problem in social life. Objectives: This case, the reasercher do the research to know the fostered parents for the independence of children in kindergarten Widya Bakti Nongan Village, Rendang, Karangasem district Methodology: The research used quantitative methods descriptive Cross Sectional, with the number of samples from 38. The sampling method used non probability sampling, that the Instrument data collection using a questionnaire pattern of fostered children and the parent The data were analyzed using Spearman' S Rho. Result: The Results showed by majority of the parent were a good enough categoried, the respondent or as many as $20 \%$ 52,6.The results of the analyzed showed most of the dependants independence has a developed independence as expected, the respondents was 23 or about 60,5\%. The analyzed using the Spearman' Rho p-value or the value = 0,000 meaning $p$ value $\leq 0,05$ the Correlation Coefficient $(r)$ of 0,851. The resoult indicated that the method in relationship between the parents whith the childrend was strongge in Widya bakti kindegarten in Nongan village. Conclusion: Based on the research wes expected to parents especially one having a preschool age children to care for the given the so as not to disturb the mental development.

Keywords: Parenting style; child independence.

\section{PENDAHULUAN}

Anak Usia 4-6 tahun adalah individu yang sedang mengalami proses pertumbuhan dan perkembangan yang sangat pesat. Anak usia dini memiliki rentang usia yang berharga dibandingkan dengan usia selanjutnya karena perkembangan kecerdasanya sangat luar biasa. Usia tersebut merupakan fase kehidupan yang sangat unik, dan berada pada proses perubahan berupa pertumbuhan, perkembangan, pematagan, dan penyempurnaan, baik pada aspek jasmani maupun rohaninya yang berlangsung seumur hidup, bertahap dan berkesinambungan Seiring berkembangnya keterampilan yang telah dikuasai oleh anak, diharapkan anakanak dapat belajar mandiri dengan merawat dirinya sendiri, dalam memenuhi kebutuhannya, seperti melepas dan mengenakan pakaian, buang air kecil, ataupun memakai kaos kaki dan sepatunya sendiri tanpa bantuan orang tua maupun pengasuhnya (H.E Mulyasa, 2012).
Kemandirian anak prasekolah di negara berkembang dan maju adalah $53 \%$ mandiri tidak tergantung pada orang lain dan 9\% masih tergantung pada orang tua, anak prasekolah $38 \%$ yang tergantung sepenuhnya pada orang tua maupun pada pengasuh mereka dan 17\% cukup mandiri. Profil masalah kesehatan perkembangan anak pada tahun 2010 dilaporkan bahwa dari jumlah anak sebanyak 3.634.505 jiwa, ditemukan 54,03\% anak dideteksi memiliki kemampuan sosialisasi dan kemandirian yang baik, cakupan tersebut masih di bawah target yakni 90\% (Depkes RI, 2010).

Ada dua faktor yang mempengaruhi kemandiri anak yaitu faktor internal dan faktor eksternal. Faktor internal misalnya kondisi fisiologi dan kondisi psikologi, dan fakto reksternal yaitu lingkungan, rasa cinta dan kasih sayang, pola asuh orang tua dalam keluarga, pengalaman dalam kehidupan. Anak yang tidak mandiri akan berpengaruh negatif terhadap perkembangan kepribadiannya sendiri. 
AA. Kompiang Ngurah Darmawan \& Ni Putu Amelia Puspita: Hubungan Pola Asuh Orang Tua terhadap Kemandirian Anak di TK Widya Bakti Desa Nongan, Kecamatan Rendang, Kabupaten

Jika hal ini tidak segera teratasi, anak akan mengalami kesulitan pada perkembangan selanjutnya. Adapun faktor yang menghambat kemandirian anak yaitu bantuan yang berlebihan, rasa bersalah orang tua, terlalu melindungi, perhatian atau ketidaktauan berlebih berpusat pada diri sendiri. Di antara sekian banyak faktor tersebut, orang tua dalam banyak hal menempati peranan yang sangat penting dalam kehidupan seorang anak. Orang tua sangat di butuhkan dalam rangka menumbuhkan sikap dan kemandirian anak (Banawati, 2017)

Kemandirian pada anak berawal dari keluarga serta dipengaruhi oleh pola asuh orang tua. Di dalam keluarga, orang tualah yang berperan dalam mengasuh, membimbing dan membantu mengarahkan anak untuk menjadi mandiri. Masa anak-anak merupakan masa yang paling penting dalam proses perkembangan kemandirian, maka pemahaman dan kesempatan yang diberikan orang tua kepada anakanaknya dalam meningkatkan kemandirian sangatlah krusial. Meskipun dunia sekolah juga turut berperan dalam memberikan kesempatan kepada anak untuk mandiri, keluarga tetap merupakan pilar utama dan pertama dalam pembentukan kemandirian anak (Irsan, 2013). Berdasarkan penelitian yang dilakukan oleh Kustiah Sunarty (2016) dengan judul Hubungan Pola Asuh Orang tua Dan Kemandirian Anak di SMPN 1 makasar, hasil yang didapat dari penelitian ini adalah ada hubungan yang positif dan signifikan antara pola asuh orang tua dan kemandirian anak.

Berdasarkan studi pendahuluan yang dilakukan di TK Widya Bakti Desa Nongan, pada tanggal 10 september 2018 didapatkan hasil observasi terhadap 10 orang anak, bahwa 4 orang anak terlihat mandiri.
Misalnya ketika waktu makan, mereka mempersiapkan alat makan sendiri dan mengambil makanan sendiri sementara 6 orang anak terlihat kurang mandiri dan ketika makan lebih senang disuap oleh orang tuanya. Setelah dilakukan wawancara dengan 10 orang tua anak tersebut, 4 dari orang tua yang anaknya tampak aktif dan lebih mandiri mengatakan bahwa mereka membiasakan anak untuk melakukan atau memilih sesuatu sesuai dengan apa yang diinginkan oleh anak misalnya berpakaian sendiri, pakai sepatu sendiri atau belajar makan sendiri dan kadangkadang mereka mengajak anak untuk melakukan hal-hal kecil dalam membantu pekerjaan rumah. Sementara 6 orang tua dari anak yang tampak kurang aktif dan kurang mandiri, mereka mengatakan bahwa mereka jarang melibatkan anak dalam memilih atau melakukan sesuatu, hal yang berkaitan dengan anak lebih banyak ditentukan oleh orang tua dan ketika anak-anak merengek-rengek meminta sesuatu, dari pada anak rewel, orang tua cenderung menuruti apa yang diinginkan oleh anak.

Berdasarkan uraian di atas maka perlu dilakukan penelitian untuk mengkaji masalah ini melalui penelitian yang diformulasikan dengan judul: "Hubungan Pola Asuh Orang Tua Terhadap Kemandirian Anak di TK Widya Bhakti Desa Nongan, Kecamatan Rendang Kabupaten Karangasem".

\section{TUJUAN PENELITIAN}

Tujuan penelitian ini adalah untuk mengetahui hubungan pola asuh orang tua terhadap kemandirian anak di TK Widya Bhakti Desa Nongan, Kecamatan Rendang Kabupaten Karangasem. 
AA. Kompiang Ngurah Darmawan \& Ni Putu Amelia Puspita: Hubungan Pola Asuh Orang Tua terhadap Kemandirian Anak di TK Widya Bakti Desa Nongan, Kecamatan Rendang, Kabupaten

\section{METODE PENELITIAN}

Rancangan

penelitian

merupakan hasil akhir dari suatu keputusan yang dibuat oleh peneliti yang berhubungan dengan bagaimana penelitian tersebut diterapkan. Pendekatan kuantitatif deskriptif, dengan menggunakan desain cross sectional, yaitu penelitian yang menekankan waktu pengukuran atau observasi data variabel independen dan variabel dependen hanya sekali saja pada suatu saat (point time approach). Jenis penelitian ini adalah penelitian deskriptif korelasional yang bertujuan untuk mengetahui tingkat hubungan antara dua variabel atau lebih, tanpa melakukan perubahan, tambahan atau manipulasi data yang memang sudah ada (Arikunto,2013).

Populasi adalah keseluruhan dari kumpulan kelompok yang memiliki sejumlah karakteristik umum, yang terdiri dari bidang-bidang untuk diteliti (Amirullah, 2015). Populasi dalam penelitian ini sebanyak 38 orang tua yang memiliki anak usia prasekolah di TK Widya Bakti Desa Nongan, Kecamatan Rendang, Kabupaten Karangasem.

Tehnik Sampling adalah suatu proses dalam menyeleksi porsi dari populasi untuk dapat mewakili populasi (Nursalam, 2016). Teknik sampling adalah suatu proses seleksi sampel yang digunakan dalam penelitian dari populasi yang ada, sehingga jumlah sampel akan mewakili keseluruhan populasi yang ada (Hidayat, 2014). Teknik pengambilan sampel yang digunakan adalah jenis non probability sampling jenis Total sampling atau sampling jenuh yaitu teknik penentuan sampel bila seluruh anggota populasi digunakan sebagai sampel (Hidayat, 2014).
Proses analisis data penelitian ini dilakukan dengan analisis univariat dan bivariat.

a. Analisis Univariat

Analisis univariat, yaitu analisis yang dilakukan pada tiap tabel dari hasil penelitian dan pada umumnya dalam analisis ini dapat menghasilkan distribusi dan presentase dari tiap variabel. Analisis ini dimaksudkan untuk mengetahui distribusi dari variabel-variabel yang diamati sehingga dapat mengetahui gambaran tiap variabel. Adapun data yang dianalisis secara univariat meliputi data pola asuh orang tua dan kemandirian anak

b. Analisis Bivariat

Uji analisis yang digunakan dalam penelitian ini adalah analisis korelasi. Analisis ini untuk menganalisis hubungan antara dua variabel yaitu keeratan hubungan, arah hubungan, dan signifikan atau tidaknya hubungan. Mengetahui keeratan hubungan antara variabel dapat dilihat pada besarnya koefesiensi korelasi, mengetahui arah hubungan dapat dilihat pada tanda koefesien korelasi positif atau negatif. Untuk mengetahui berarti atau tidak adanya hubungan dilakukan uji signifikansi. Uji analisis korelasi yang akan digunakan pada penelitian ini adalah uji korelasi Rank Spearman dengan tingkat kemaknaan $\alpha=0,05$. Apabila nilai Probability (p) $>0,05$ maka hipotesa nol diterima atau sebaliknya.

\section{HASIL PENELITIAN}

Hasil analisis univariat menjelaskan tentang karakteristik responden, pola asuh orang tua dan tingkat kemandirian anak di TK Widya Bakti Desa Nongan, Kecamatan Rendang, Kabupaten Karangasem. Hasil analisis univariat diuraikan sebagai berikut: 
AA. Kompiang Ngurah Darmawan \& Ni Putu Amelia Puspita: Hubungan Pola Asuh Orang Tua terhadap Kemandirian Anak di TK Widya Bakti Desa Nongan, Kecamatan Rendang, Kabupaten

Tabel 1. Distribusi Frekuensi Karakteristik Responden Berdasarkan Usia

\begin{tabular}{cccccc}
\hline $\begin{array}{c}\text { Usia } \\
\text { Orang } \\
\text { Tua } \\
\text { (Tahun) }\end{array}$ & N & Min & Max & Mean & $\begin{array}{c}\text { Std. } \\
\text { Deviation }\end{array}$ \\
\cline { 2 - 6 } & & 25 & 37 & 30,39 & 3,301 \\
\hline
\end{tabular}

Tabel 5.1 menunjukkan bahwa usia terendah responden adalah 25 tahun dan usia tertinggi adalah 37 tahun dengan rerata usia responden adalah 30,39 tahun.

Tabel 2. Distribusi Frekuensi Karakteristik Responden Berdasarkan Pendidikan

\begin{tabular}{ccc}
\hline Pendidikan & $\begin{array}{c}\text { Frekuensi } \\
\text { (f) }\end{array}$ & $\begin{array}{c}\text { Persentase } \\
(\mathbf{\%})\end{array}$ \\
\hline SD & 2 & 5,3 \\
\hline SMP & 5 & 13,2 \\
\hline SMA/SMK & 20 & 52,6 \\
\hline Perguruan Tinggi & 11 & 28,9 \\
\hline Total & 38 & 100 \\
\hline
\end{tabular}

Tabel 5.2 menunjukkan bahwa sebagian besar responden memiliki pendidikan terakhir pada tingkat SMA/SMK, yaitu sebanyak 20 responden $(52,6 \%)$.

Tabel 3. Distribusi Frekuensi Hasil Identifikasi Pola Asuh Orang Tua di TK Widya Bakti Desa Nongan, Kecamatan

Rendang, Kabupaten Karangasem

\begin{tabular}{lcc}
\hline Kategori & $\begin{array}{c}\text { Frekuensi } \\
\text { (f) }\end{array}$ & $\begin{array}{c}\text { Persentase } \\
(\mathbf{\%})\end{array}$ \\
\hline $\begin{array}{l}\text { Sangat } \\
\text { Baik }\end{array}$ & 0 & 0 \\
\hline Baik & 18 & 47,4 \\
\hline $\begin{array}{l}\text { Cukup } \\
\text { baik }\end{array}$ & 20 & 52,6 \\
\hline $\begin{array}{l}\text { Kurang } \\
\text { baik }\end{array}$ & 0 & 0 \\
\hline Total & 38 & 100 \\
\hline
\end{tabular}

Tabel 5.3 menunjukkan bahwa sebagian besar pola asuh orang tua berada pada kategori cukup baik, yaitu sebanyak 20 responden dengan persentase sebesar 52,6\%.

Tabel 4. Distribusi Frekuensi Hasil Identifikasi Tingkat Kemandirian Anak di TK Widya Bakti Desa Nongan, Kecamatan Rendang, Kabupaten

\begin{tabular}{lcc}
\hline Kategori & Karangasem & \\
\hline $\begin{array}{l}\text { Berkembang } \\
\text { sangat baik }\end{array}$ & 15 & $\begin{array}{c}\text { Persentase } \\
(\mathbf{\%})\end{array}$ \\
\hline $\begin{array}{l}\text { Berkembang } \\
\text { sesuai } \\
\text { harapan }\end{array}$ & 23 & 39,5 \\
\hline $\begin{array}{l}\text { Mulai } \\
\text { Berkembang }\end{array}$ & 0 & 60,5 \\
\hline $\begin{array}{l}\text { Tidak } \\
\text { Berkembang }\end{array}$ & 0 & 0 \\
\hline Total & 38 & 0 \\
\hline
\end{tabular}

Tabel 5.4 menunjukkan bahwa sebagian besar anak memiliki tingkat kemandirian yang telah berkembang sesuai harapan, yaitu sebanyak 23 responden dengan persentase sebesar $60,5 \%$.

Pada hasil uji bivariat akan disajikan hasil analisa pengaruh pemberian jus tomat dan mentimun terhadap tekanan darah tinggi pada penderita hipertensi dengan overweight di Banjar Bunutan, Desa Bunutan, Karangasem

Tabel 5. Uji Bivariat

\begin{tabular}{|c|c|c|c|c|}
\hline & & & $\begin{array}{c}\text { Pola Asuh } \\
\text { Orang } \\
\text { Tua }\end{array}$ & $\begin{array}{c}\text { Kemandirian } \\
\text { Anak }\end{array}$ \\
\hline \multirow[t]{6}{*}{$\begin{array}{l}\text { Spearm } \\
\text { an's rho }\end{array}$} & \multirow{3}{*}{$\begin{array}{l}\text { Pola } \\
\text { Asuh } \\
\text { Orang } \\
\text { Tua }\end{array}$} & $\begin{array}{l}\text { Correlation } \\
\text { Coefficient }\end{array}$ & 1.000 & $.851^{* *}$ \\
\hline & & $\begin{array}{l}\text { Sig. (2- } \\
\text { tailed) }\end{array}$ & & .000 \\
\hline & & $\mathrm{N}$ & 38 & 38 \\
\hline & \multirow{3}{*}{$\begin{array}{l}\text { Kema } \\
\text { ndirian } \\
\text { Anak }\end{array}$} & $\begin{array}{l}\text { Correlation } \\
\text { Coefficient }\end{array}$ & $.851^{* *}$ & 1.000 \\
\hline & & $\begin{array}{l}\text { Sig. (2- } \\
\text { tailed) }\end{array}$ & .000 & \\
\hline & & $\mathrm{N}$ & 38 & 38 \\
\hline
\end{tabular}


AA. Kompiang Ngurah Darmawan \& Ni Putu Amelia Puspita: Hubungan Pola Asuh Orang Tua terhadap Kemandirian Anak di TK Widya Bakti Desa Nongan, Kecamatan Rendang, Kabupaten

Tabel 5.5 menunjukkan hasil analisis pada kedua variabel menggunakan uji Spearman's rho didapatkan nilai signifikan atau $p$ value $=0,000$ yang berarti nilai $\mathrm{p} \leq 0,05$ dengan nilai Correlation Coefficient (r) sebesar 0,851. Hasil ini mengindikasikan bahwa Ho dalam penelitian ditolak yang artinya ada hubungan yang kuat antara pola asuh orang tua terhadap kemandirian anak di TK Widya Bakti Desa Nongan, Kecamatan Rendang, Kabupaten Karangasem.

PEMBAHASAN

\section{Distribusi Frekuensi Yang Mempengaruhi Kemandirian Anak}

Kemandirian anak dapat dipengaruhi oleh berbagai hal salah satunya faktor peran jenis kelamin, menurut Irahayanti (2014) Secara fisik anak laki laki dan perempunan tampak jelas perbedaan dalam perkembangan kemandiriannya. Dalam perkembangan kemandirian anak laki-laki biasanya lebih aktif dari pada anak perempuan. Selain itu juga faktor lingkungan juga dapat mempengaruhi kemandirian anak dimana Lingkungan kehidupan yang dihadapi anak sangat mempengaruhi perkembangan kepribadianya, baik dan segi-segi positif maupun negatif. Biasanya lingkungan keluarga, social, masyarakat itu juga mempengaruhi perkembangan kepribadian anak. Meskipun cenderung akan dampak positif dalam hal kemandirian anak terutama dalam bidang nilai dan kebiasaan dalam melaksanakan tugastugas kehidupan.

Anak yang memiliki intelegensi yang tinggi akan lebih cepat menangkap sesuatu yang membutuhkan kemampuan berfikir. Sehingga, anak yang cerdas cenderung cepat dalam membuat keputusan untuk bertindak, disamakan dengan kemampuan menganalisis yang baik terhadap resiko resiko yang akan dihadapi. intelegensi berhubungan dengan tingkat kemandirian anak. Artinya semakin tinggi intelegensi seorang anak maka semakin tinggi pula tingkat kemandiriannya.

\section{Pola Asuh Orang Tua di TK Widya} Bakti Desa Nongan, Kecamatan Rendang, Kabupaten Karangasem

Pada penelitian ini didapatkan hasil bahwa sebagian besar pola asuh orang tua berada pada kategori cukup baik, yaitu sebanyak 20 responden dengan persentase sebesar 52,6\%. Pola asuh merupakan tingkah laku orang tua dalam membesarkan anak (Power, Sleddens, Berge, Connell, Govig, Bennessy, \& St. George, 2013). Rachmawati (2010) menjelaskan bahwa pola asuh orang tua adalah cara atau metode yang ditempuh orang tua dalam mengasuh dan menerapkan kemandirian kepada anaknya dalam membentuk watak, kepribadian, dan memberikan nilai-nilai bagi anak agar dapat menyesuaikan diri dengan lingkungan. Setiap keluarga memiliki pola asuh yang berbeda dalam mendidik seorang anak dan biasanya diturunkan oleh pola asuh yang diterima dari orang tua sebelumnya (Ayun, 2017). Pola asuh orang tua bergantung pada pola pikir yang dimiliki oleh orang tua yang dapat dipengaruhi oleh budaya, pendidikan, usia ataupun status ekonomi. Seorang ibu yang telah memiliki kedewasaan yang cukup dan emosi yang stabil akan lebih matang dalam pengambilan keputusan terkait pola asuh yang akan diterapkan karena sangat berkaitan dengan perkembangan anak (Mardiyanti \& Kurniawati, 2017).

Hasil penelitian ini sesuai dengan penelitian Rahnawati (2015) yang menyatakan bahwa sebagian besar orang tua memiliki pola asuh yang cukup baik, yaitu sebanyak 49,09\% dengan nilai $p$-value $=0,000$. 
AA. Kompiang Ngurah Darmawan \& Ni Putu Amelia Puspita: Hubungan Pola Asuh Orang Tua terhadap Kemandirian Anak di TK Widya Bakti Desa Nongan, Kecamatan Rendang, Kabupaten

Berdasarkan temuan pada penelitian ini, peneliti memiliki opini bahwa cukup baiknya pola asuh yang diberikan orang tua dapat terjadi karena sebagian besar orang tua telah mengajarkan anak dan membiasakan anak bersikap positif seperti memberikan bantuan pada setiap pekerjaan. Hal ini sesuai dengan ratarata jawaban orang tua pada kuesioner yang sebagian besar telah mengajarkan anak berbagai kebiasaan-kebiasaan dan sikap yang baik.

Tingkat Kemandirian Anak di TK Widya Bakti Desa Nongan, Kecamatan Rendang, Kabupaten Karangasem

Pada penelitian ini didapatkan hasil bahwa sebagian besar anak memiliki tingkat kemandirian yang telah berkembang sesuai harapan, yaitu sebanyak 23 responden dengan persentase sebesar $60,5 \%$. Kemandirian merupakan aspek yang berkembang dalam diri setiap individu, yang bentuknya sangat beragam, tergantung pada proses perkembangan dan proses belajar yang dialami masing-masing individu (Sunarty, 2016). Kemandirian individu tercermin dalam cara berpikir dan bertindak, kemampuan mengambil keputusan, pengarahan dan pengembangan diri serta penyesuaian diri secara konstruktif dengan norma yang berlaku di lingkungannya (Wiyani, 2014).

Kemandirian sangat erat kaitannya dengan anak sebagai individu yang mempunyai konsep diri, penghargaan terhadap diri sendiri dan mengatur diri sendiri. Kemandirian bisa dilihat dari tingkah laku, tetapi kemandirian tidak selalu berbentuk fisik yang ditampilkan dalam tingkah laku, sebab kemandirian dapat pula dilihat dari bentuk emosional dan sosialnya (Komala, 2015). Kemandirian berkembang secara bertahap sesuai dengan tingkatan perkembangan seseorang. Sesuai dengan bertambahnya umur, pertumbuhan dan perkembangan akan mengalami peningkatan, salah satunya adalah kecenderungan untuk melepaskan diri dari ketergantungan orang lain. Kemandirian juga erat kaitannya dengan disiplin, maka mengajarkan disiplin kepada anak sejak dini, berarti telah melatih anak untuk bisa mandiri di masa datang (Nafiah, 2018).

Hasil penelitian sejalan dengan penelitian yang dilakukan Riyadi (2016) yang menyatakan bahwa sebagian besar tingkat kemandirian anak berada pada kriteria berkembang sesuai harapan (BSH) yaitu sebanyak 14 anak (52\%) $(\mathrm{p}=0,000)$. Berdasarkan temuan pada penelitian ini, peneliti memiliki opini bahwa tingkat kemandirian anak yang telah berada pada kategori baik yakni telah berkembang sesuai harapan dapat terjadi karena anak telah mampu menunjukkan perilaku kemandirian yang telah dikembangkan oleh orang tua, terutama kemandirian dalam hubungan sosial. Hal ini sesuai dengan rata-rata jawaban responden pada kuesioner yang menyatakan bahwa kemandirian anak lebih banyak ditunjukkan melalui pergaulan anak yang sangat disenangi oleh temantemannya dilingkungan rumah dan sekolah. (2013) yang menyatakan bahwa penderita hipertensi yang mempunyai pekerjaan terbanyak sebagai wiraswasta dengan jumlah 12 responden $(40 \%)$.

Analisa Hubungan Pola Asuh Orang Tua Terhadap Kemandirian Anak di TK Widya Bakti Desa Nongan, Kecamatan Rendang, Kabupaten Karangasem

Pada penelitian ini didapatkan hasil bahwa ada hubungan yang kuat antara pola asuh orang tua terhadap kemandirian anak di TK Widya Bakti 
AA. Kompiang Ngurah Darmawan \& Ni Putu Amelia Puspita: Hubungan Pola Asuh Orang Tua terhadap Kemandirian Anak di TK Widya Bakti Desa Nongan, Kecamatan Rendang, Kabupaten

Desa Nongan, Kecamatan Rendang, Kabupaten Karangasem dengan nilai pvalue $=0,000$ dan nilai Correlation Coefficient (r) sebesar 0,851. Desmita (2011) bahwa kunci kemandirian ada ditangan orang tua. Kemandirian yang dihasilkan melalui bimbingan dan kehadiran orang tua adalah kemandirian yang utuh. Pola asuh orang tua memiliki peran dalam pembentukan sikap seorang anak. Semakin tinggi pola asuh yang diterapkan orang tua maka tanggung jawab anak menjadi tinggi. (Annarisa, 2014).

Pola asuh orang tua memegang peranan penting bagi perkembangan kemandirian anak. Cara asuh yang berbeda-beda akan menghasilkan kemandirian yang berbeda pada anak, sebab perkembnagan kemandirian tidak terlepas dari penerapan pola asuh orang tua melalui interaksi orang tua dan anak. Orang tua merupakan lingkungan pertama yang paling berperan dalam pola asuh anaknya, sehingga mempunyai pengaruh yang paling besar terhadap pembentukan kemandirian (Santosa \& Marheni, 2015). Pola asuh yang tepat akan memberikan ruang gerak bagi perkembangan anak secara umum yang meliputi perkembangan intelektualnya, perkembangan emosinya, perkembangan sosial. Pola asuh yang baik akan merangsang perkembangan anak menjadi lebih baik sesuai dengan usia anak dan dapat berperan pada kemandirian anak. Sebaliknya, pola asuh yang salah akan menimbulkan mental yang tidak sehat pada anak, sehingga dapat membuat anak tidak memiliki kemauan dan kemampuan untuk melakukan sesuatu dengan mandiri (Mu'tadin dalam Julianto, 2015).

Temuan pada penelitian ini sejalan dengan penelitian yang dilakukan oleh Suseno (2010) yang menyatakan bahwa ada hubungan antara pola asuh orang tua dengan kemandirian anak usia prasekolah di TK Aisyiyah Mendungan Sukoharjo dengan nilai $\mathrm{p}$ value $(0,000)<\alpha(0,05)$. Penelitian oleh Tsani, Herawati \& Istianti (2016) juga sesuai dengan hasil penelitian yang menyatakan bahwa terdapat hubungan yang sangat tinggi antar pola asuh orang tua dengan kemandirian anak usia dini taraf signifikan 0,05.

Berdasarkan temuan pada penelitian ini, peneliti berasumsi bahwa adanya hubungan pola asuh orang tua dengan tingkat kemandirian anak dapat terjadi karena dukungan dan edukasi yang diberikan orang tua. Hal ini dibuktikan dengan rata-rata jawaban responden pada kuesioner yang menyatakan bahwa sebagian besar telah mengajarkan anak untuk belajar mandiri misalnya dengan mengajarkan anak untuk mengatur segala kebutuhan yang diperlukan secara mandiri serta memberikan dukungan kepada anak untuk dapat melakukan sesuatu yang baik secara mandiri.

\section{KESIMPULAN}

Adapun simpulan yang dapat ditarik pada penelitian ini, diantaranya:

1. Pola asuh orang tua sebagian besar berada pada kategori cukup baik, yaitu sebanyak 20 responden dengan persentase sebesar $52,6 \%$.

2. Tingkat kemandirian anak sebagian besar telah berkembang sesuai harapan, yaitu sebanyak 23 responden dengan persentase sebesar $60,5 \%$.

3. Ada hubungan yang kuat antara pola asuh orang tua terhadap kemandirian anak di TK Widya Bakti Desa Nongan, Kecamatan Rendang, Kabupaten Karangasem dengan nilai $\mathrm{p}$-value $=0,000$ dan nilai Correlation Coefficient (r) sebesar 0,851. 
AA. Kompiang Ngurah Darmawan \& Ni Putu Amelia Puspita: Hubungan Pola Asuh Orang Tua terhadap Kemandirian Anak di TK Widya Bakti Desa Nongan, Kecamatan Rendang, Kabupaten

DAFTAR PUSTAKA

Panduan Untuk Orang Tua. Jakarta: PT Elex Media Komputindo.

Amirullah. (2015). Pengantar Manajemen. Jakarta: Mitra Wacana Media.

Annarisa, E. (2014). Hubungan Pola Asuh Orang Tua Dengan Tanggung Jawab Pelaksanaan Tugas Sekolah Di TK Islam Bakti IV Pekalongan Tahun Ajaran 2013/2014 (Doctoral dissertation, Universitas Muhammadiyah Surakarta).

Ayun, Q. (2017). Pola Asuh Orang Tua Dan Metode Pengasuhan Dalam Membentuk Kepribadian Anak. ThufuLA: Jurnal Inovasi Pendidikan Guru Raudhatul Athfal, 5(1), 102-122.

Arikunto, S. (2013). Prosedur Penelitian. Jakarta: PT. Rineka Cipta.

Banawati (2017) pola asuh orang tua dalam mengembangkan kemandirian anak usia dini di dukuh branglor mancasan baki sukoharjo tahun 2017. skripsi thesis, IAIN Surakarta.

Brewer dalam Yamin. Sabari (2013). Panduan PAUD (Pendidikan Anak Usia Dini). Jambi: Referensi.

Carol Cooper (2009:169). Ensiklopedia Perkembangan Anak. Erlangga.

Daniel Bokko, (2014) Hubungan Pola Asuh Orang Tua Dengan Tingkat Kemandirian Anak Usia Pra Sekolah Di Kelurahan Pantan Kabupaten Tana Toraja. Jurnal Keguruan dan Ilmu Pendidikan Vol III No. 1, MaretJuni 2014.

Dariyo, Agoes. (2011). Psikologi Perkembangan. Bandung: PT. Refika Aditama.

Depkes RI. 2010. Instrumen Stimulasi, Deteksi dan Intervensi Dini
Tumbuh Kembang Anak. Jakarta: Departemen Kesehatan RI.

Desmita. (2011). Psikologi Perkembangan Peserta Didik Bandung : Remaja Rosda Karya.

Hasan Maimunah. (2010). Pendidikan Anak Usia Dini (PAUD). Jogjakarta: DIVA press.

Hidayat, A. (2014). Riset Keperawatan dan Teknik Penulisan Ilmiah. Jakarta: Salemba Medika.

Irahayanti dalam Basri, Hasan.2014. Landasan Pendidikan.Bandung : Pustaka Setia.

Irsan, Ns. (2013). Hubungan Antara Pola Asuh Orangtua dengan Kemandirian Anak Usia Prasekolah di TK Kamalilah Kuta Baro Aceh Besar tahun 2012. STIKES: Banda Aceh.

Julianto, A. P. (2015). Hubungan Pola Asuh Orang Tua dengan Tingkat Kemandirian Anak Usia Sekolah Di SDN Panjang Wetan 01 Pekalongan. Pena Medika Jurnal Kesehatan, 2(2).

Kohn dalam Hawadi (2013: 10-11). Komunikasi Dalam Pengasuhan. Jakarta: Kementerian Pendidikan Dan Kebudayaan.

Komala, K. (2015). Mengenal Dan Mengembangkan Kemandirian Anak Usia Dini Melalui Pola Asuh Orang Tua dan Guru. Tunas Siliwangi: Jurnal Program Studi Pendidikan Guru PAUD STKIP Siliwangi Bandung, 1(1), 31-45.

Lestari. (2013). Hubungan Pola Asuh Orang Tua Dengan Disiplin Belajar Siswa Kelas IV Dan V Sekolah Dasar Negeri Se-Gugus 1 Sidoarum Kecamatan Godean Kabupaten Sleman. Jurnal Ilmiah Pendidikan Bimbingan Dan Konseling. Vol. 1 No. 1, April 2013. 
AA. Kompiang Ngurah Darmawan \& Ni Putu Amelia Puspita: Hubungan Pola Asuh Orang Tua terhadap Kemandirian Anak di TK Widya Bakti Desa Nongan, Kecamatan Rendang, Kabupaten

Mardiyanti, I., \& Kurniawati, L. D. (2017). Pola asuh orang tua mempengaruhi perkembangan balita di Posyandu Arjuna RW IV Pos 3 Kelurahan Kemayoran Kecamatan Krembangan Surabaya. Journal of Health Sciences, 7(1).

Mulyasa, HE. (2012).Manajemend Paud. Bandung: PT. Remaja Rosdakarya.

Nafiah, U. (2018). Pengaruh Pola Asuh Otoriter terhadap Sikap Kemandirian Anak Usia Dini di Raudhatul Athfal Miftahus Salam Kaliwates Jember. Tersedia pada http://repository.unej.ac.id/handl e/123456789/79893.

Notoatmojo, S. (2012). Metode Penelitian Kesehatan. Jakarta; Rineka Cipta.

Nurhayati, Eti. (2011). Psikologi Pendidikan Inovatif. Yogyakarta: Pustaka Pelajar.

Power, T. G., Sleddens, E. F., Berge, J., Connell, L., Govig, B., Hennessy, E., \& St. George, S. M. (2013). Contemporary research on parenting: conceptual, methodological, and translational issues. Childhood Obesity, 9(s1), S-87.

Rachmawati, Euis Kurniati. 2010. Strategi Mengembangkan Kreativitas Pada Anak Usia Taman Kanak-Kanak. Jakarta: Kencana Prenada Media Group.

Rahnawati, E. D. (2015). Pengaruh Pola Asuh Orang Tua Terhadap Kemandirian Belajar Siswa Kelas XI Tsm Smk N 8 Purworejo. OIKONOMIAJurnal Pendidikan Ekonomi, 2(4).

Renita Mulyaningtyas, Yusup Purnomo Hadiyanto. 2007. Bimbingan Dan Konseling. Riyadi, E. N.
(2016). Tingkat Kemandirian Anak Taman Kanak-Kanak Mutiara Insani. Pendidikan Guru PAUD S-1, 5(7), 690698.Jakarta: PT Gelora Aksara Pratama.

Rosalina Anita. (2009). Buku Panduan Program Pembelajaran Untuk Menstimulasi Keterampilan Sosial Anak Bagi Pendidik Taman KanakKanak.Yogyakarta: Logung Pustaka.

Sochib, Moh. (2010). Pola asuh orang tua dalam membentuk anak dalam mengembangkan disiplin diri. Jakarta: PT. Rineka Cipta.

Sunarty, K. (2014). Model Pola Asuh Orangtua untuk Meningkatkan Kendirian Anak. Disertasi. Tidak Diterbitkan. Makassar: Program Pascasarjana UNM.

Suseno, D. D. (2010). Hubungan Antara Pola Asuh Orang Tua dengan Kemandirian Anak Usia Prasekolah di TK Aisyiyah Mendungan Sukoharjo (Doctoral dissertation, Universitas Muhammadiyah Surakarta). http://eprints.ums.ac.id/10439/.

Tsani, I. L., Herawati, N. I., \& Istianti, T. (2016). Hubungan Pola Asuh Orang Tua Dengan Kemandirian Anak Usia Dini. Cakrawala Dini: Jurnal Pendidikan Anak Usia Dini, 7(2).

Wahyuning, W. (2010). Mengkomunikasikan Moral Kepada Anak. Jakarta: PT Alex Media Komputindo.

Widyarini. (2014). Hubungan Pola Asuh Orang Tua Dengan Prestasi Belajar Anak Usia Sekolah Dasar Kelas II Dan III. Jurnal ilmiah pendidikan bimbingan dan konseling. Vol 1 no. 1, oktober 2014. 
AA. Kompiang Ngurah Darmawan \& Ni Putu Amelia Puspita: Hubungan Pola Asuh Orang Tua terhadap Kemandirian Anak di TK Widya Bakti Desa Nongan, Kecamatan Rendang, Kabupaten

Karangasem

Wiyani, N. A. (2014). Psikologi

perkembangan anak usia dini.

Yogyakarta: Gava Media.

Yusuf, (2013). Psikologi Perkembangan

Anak dan Remaja. Bandung: PT.

Remaja Rosda. 